Gelbe, verdickte Nägel

\title{
Die antimykotische Therapie war erfolglos - was nun?
}

\section{Anamnese}

Der 44-jährige Patient bemerkte seit etwa einem Jahr eine Gelbverfärbung und Verdickung sämtlicher Nägel, deren Wachstum komplett sistierte. Eine interne antimykotische Therapie aufgrund einer Onychomykose der Fußnägel blieb an den Fingernägeln sine effectu. Weitere Erkrankungen bestünden nicht.

Wie lautet Ihre Verdachtsdiagnose?

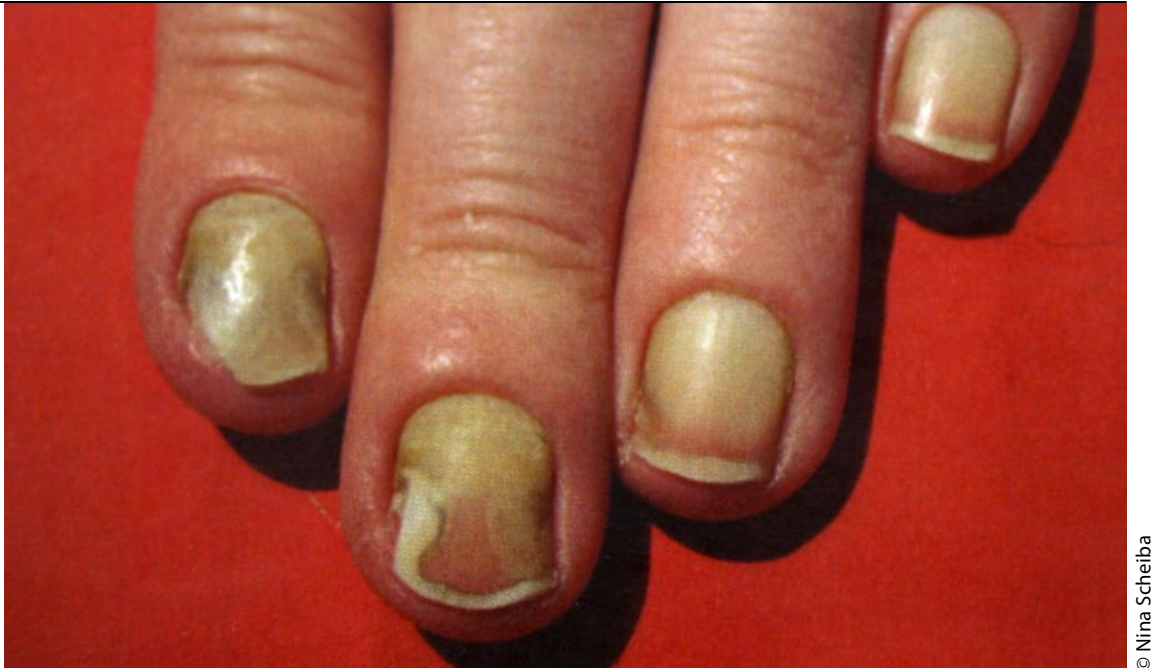

Abb. 1: gelb verfärbte Fingernägel des Patienten

\section{Blickdiagnosen auf springermedizin.de}

Weitere Fälle, bei denen Ihr diagnostischer Spürsinn gefragt ist, stehen für Sie online in der Rubrik „Blickdiagnose interaktiv“ bereit: www.springermedizin.de/blickdiagnose-interaktiv

Eine Sammlung interessanter Kasuistiken aus der Praxis finden Sie außerdem im Dossier „Blickdiagnosen aus der Praxis”: www.springermedizin.de/307330 